\title{
Agenda dynamics in Latin America: theoretical and empirical opportunities
}

Frank R. Baumgartner ${ }^{1}$

Bryan D. Jones ${ }^{2}$

Laura Chaqués Bonafont ${ }^{3}$

1 University of North Carolina at Chapel Hill, North Carolina - United States of America

2 University of Texas at Austin, Texas - United States of America

${ }^{3}$ Institut Barcelona d'Estudis Internacionals, Barcelona - Spain

The Comparative Agendas Project (CAP) collects, organizes, and makes freely available millions of bits of information concerning the objects of government attention over long periods of time (often back to the Second World War) for more than 25 political systems, worldwide. As researchers affiliated with the CAP expand their projects into Latin America, they confront some challenges similar to those from other regions, and some unique to their national political systems. In this introductory essay, we explore the background of the CAP and the opportunities posed by its expansion into Latin American political systems.

Keywords: comparative agendas project; agenda-setting; public policy; policy process; political institutions.

\section{Dinâmicas da Agenda de Políticas Públicas na América Latina: Oportunidades Teóricas e Empíricas}

O Comparative Agendas Project (CAP) coleta, organiza e disponibiliza gratuitamente milhões de dados sobre os temas que têm chamado a atenção de governos em mais de 25 sistemas políticos de todo mundo. Os dados disponíveis compreendem um longo período desde a Segunda Guerra Mundial. Na expansão de seus projetos para a América Latina, os pesquisadores ligados ao CAP enfrentam, além de desafios comuns aqueles encontrados globalmente, outras adversidades particulares dos sistemas políticos adotados nas nações da região. Neste ensaio introdutório, exploramos os antecedentes do CAP e as oportunidades que se apresentam com sua expansão aos sistemas políticos latino-americanos.

Palavras-chave: comparative agendas Project; política pública; processo de políticas públicas; instituições políticas.

\section{Dinámica de la Agenda de Políticas Públicas en América Latina: oportunidades teóricas y empíricas}

El Comparative Agendas Project (CAP, por sus siglas en inglés) recopila, organiza y pone a disposición de forma gratuita millones de datos sobre los temas que han sido priorizados por parte de políticos y gobernantes en más de 25 sistemas políticos de todo el mundo. Estas bases de datos abarcan un período de tiempo largo, que en la mayoría de casos comienza tras el fin de la Segunda Guerra Mundial). Los investigadores que desarrollan proyectos siguiendo la metodología del CAP en América Latina tienen que hacer frente a los desafíos comunes que los investigadores han encontrado al analizar la agenda política, a otros exclusivos de los sistemas políticos de los países de esta región. En este ensayo introductorio, exploramos los antecedentes del CAP y las oportunidades que se presentan con su expansión a los sistemas políticos latinoamericanos.

Palabras clave: Comparative Agendas Project; agenda política; proceso de políticas públicas; instituciones políticas. 


\section{BACKGROUND ON THE COMPARATIVE AGENDAS PROJECT}

The Comparative Agendas Project (CAP) developed organically from the US-based Policy Agendas Project. Frank Baumgartner and Bryan Jones noted in the research they conducted for their 1993 book, Agendas and Instability in American Politics (Baumgartner \& Jones, 1993) that they could learn much by assessing small bits of information over long periods of time to trace the development of public policy toward a particular policy issue. They studied a handful of issues, including nuclear power, pesticides, and tobacco, tracing media coverage and US congressional hearings on those topics, noting simply whether the attention was favorable to or critical of the industry in question. The quantitative techniques they began to use in that project became the basis for a research project that began in 1994 and continues to this day. The US-based project now incorporates over a million records of US governmental activities such as bills introduced, roll call votes taken, statutes enacted, media coverage, presidential executive orders, Supreme Court decisions, and so on (see Baumgartner \& Jones, 2015; Jones \& Baumgartner, 2005).

The CAP started when Christoffer Green-Pedersen of Aarhus University visited the University of Washington in Seattle during the academic year in 2004 and realized he could potentially replicate the US based project for his native Denmark. At the same time, Baumgartner was a visiting scholar in Europe during the 2004-2005 academic year and introduced a number of audiences to the possibilities of the approach. Stefaan Walgrave at the University of Antwerp had independently developed a similar project in Belgium, and he soon realized the value of making his data consistent with others. The CAP grew quickly from this starting point to the UK, Denmark, France, Belgium, Spain, the Netherlands, Canada, and Switzerland and currently involves projects in over two dozen political systems in the US, Europe, and Asia (see Baumgartner, Breunig, \& Grossman, 2019a for more detail on the early growth of the CAP network). Expansions into Latin American political systems are, of course, the focus of our attention here.

The CAP is unified by a methodology and a series of databases, not by a single theoretical framework. The idea of the CAP is that scholars can gain by sharing infrastructure. Just as astronomers advance their discipline by building bigger telescopes, we can also gain greater insights into the actions of governments worldwide by expanding the empirical scope of our studies. Public policy studies have often focused on one policy issue at a time, or a limited number of them. The idea of the CAP is to gather information about all government activities, exhaustively. That is, rather than studying health or immigration policy, or a particular change in financial regulations, foreign policy, or defense strategies, we can learn by compiling information on all the actions of a government, across all topics of attention, and across a long time frame. The US Agendas Project databases generally extend back in time to World War Two. Some countries have databases that extend further back in time than this, though most do not go quite as far. With a long historical view and a wide empirical scope, scholars involved in the CAP seek to understand how attention moves from one topic to another. Most scholars are interested in their own countries, but the project facilitates cross-system comparisons because the topic categories used throughout the CAP projects, worldwide, are consistent. So when one tracks attention to health-care policies in Spain, one can easily replicate that analysis and compare the Spanish experience with the French, Danish, UK, or Swiss experience. 
By making data comparable, the CAP promotes comparisons and generalizability. The project, on the other hand, imposes no particular theoretical perspective. Perhaps by providing quantitative databases it can be said to promote a quantitative, rather than a qualitative, approach to the study of public policy. But even here, the project has often been used, as it was designed, to provide the quantitative background and starting point so that qualitatively-minded scholars could delve deeper into particular issues of concern, such as why a particular policy change was enacted, at a particular time, in a particular country, by a particular set of political leaders, and with what arguments and bits of evidence. After all, the project databases provide an easy introduction and indexing system to all the relevant government actions on any particular topic. So, while most CAP-related publications have indeed adopted a quantitative approach, the CAP itself does not require it and indeed can be used as the first step in a deeper qualitative approach. (For an example of such a project see Engeli, Green-Pedersen, \& Larsen, 2012, which focused on deep comparisons of "morality politics" in several countries, using the CAP data as a starting point.)

The CAP has perhaps had more influence in generating novel areas of study than in changing the study of older questions. For example, Jones and Baumgartner (2005) assessed questions about the diversity of the public agenda and the "shape of change" in public budgets. The diversity of the public agenda refers to the degree that public authorities focus their collective official attention (measured by such things as legislative activities, court decisions, media coverage of government actions, or other indicators) on just a few top priorities, or spread them across multiple topics simultaneously. It is obvious to state, but difficult to measure, that governments, through division of labor, simultaneously are involved in many different activities, tens of thousands. Which institutions have the most diverse agendas? How do political or bureaucratic leaders deal with and manage the overwhelming complexity of the diverse policy issues confronting their agencies each day? By gathering the data, we allow the analysis.

The field of budgetary politics has been changed by the CAP datasets on budgeting. By assessing the full panoply of budgets, across long periods of time and across all spending categories, scholars in the CAP tradition have noted powerful similarities across budgeting processes in every system so far analyzed, leading to the conclusion that there is an "empirical law of public budgeting" consistent with theories of bounded rationality (see Jones et al., 2009). The "shape of change" in budgets is little change most of the time for most categories, but occasional dramatic shifts (see Jones, Baumgartner, $\&$ True, 1998).

The detailed databases associated with the CAP have allowed analyses of the dynamics of politics not previously explored in detail. For example, Green-Pedersen and others have looked at the impact of opposition members' oral questions in the Danish Parliament, noting that despite their lack of constitutional power or leverage over the sitting Government, such questions may be highly newsworthy, and the resulting news coverage can push the Government to act (see Green-Pedersen \& Mortensen, 2010; Seeburg, 2013). Chaqués Bonafont, Roqué, and Baumgartner (2015) showed similar dynamics in Spain.

Public opinion scholars have long been interested in the dynamics of opinion responsiveness, or the degree to which policy changes from governments relate to shifts in public opinion and election 
results (see Erikson, Stimson, \& MacKuen, 2002; Stimson, 1999; Wlezien, 1995); since the development of the measures associated with the CAP, these questions have been addressed in novel ways (see Soroka \& Wlezien, 2010; Wlezien \& Soroka, 2012).

Without reviewing all the issues elucidated by CAP scholars using the related databases from the project, our point is simple: with a bigger telescope, we can discover more. Many of these questions were recently explored in an edited book describing the data associated with the CAP and the projects associated with it (see Baumgartner, Breunig, \& Grossman, 2019b).

\section{THE STRUCTURE OF THE CAP DATABASE}

The initial codebook associated with the US-based Policy Agendas Project enumerated approximately 235 topics of attention, a complete catalogue of activities of the US government since World War Two. When Christoffer Green-Pedersen first adopted the system to Denmark, there were of course some adjustments to make. Denmark has a monarchy; Baumgartner and Jones had not established any codes for the US system for oversight of such an organization, nor for a state religion. But every country addresses issues of the quality of its educational system, supporting its farmers, managing its coastal waters, building dams and transportation infrastructure, and so on. Geeen-Pedersen's adjustments to the list of topics were surprisingly few. In the end, the master topic codebook of the Comparative Agendas Project differs from the one developed originally with only the US political system in mind, but less than one might have expected. Governments everywhere (at least in the political systems so far explored in the CAP) have a common set of areas of activity. Indeed, some of the biggest adjustments have been in the detailed coding of the Pennsylvania Policy Database Project, which documented a range of activities simply not accounted for in the national government, such as licensing of professions or regulating the activities of townships, municipalities, counties, and local government entities of various kinds. Sovereign national governments have more in common cross-nationally than they may have in common with their own subunits.

As the various country projects moved forward, sometimes adding new codes to address particular issues faced by those projects, a critical trade-off became evident. The more a country coding system addresses the peculiarities of country, the less the policy development in that country may be compared to other countries. As a consequence, under the guidance of Sean Bevan of the University of Edinburgh, the CAP community developed a master codebook based on 20 major topics and 225 minor topics. The minor topics are hierarchically arranged. All country systems are constructed so that they can be mapped into the master CAP system, so that each country is directly comparable to all others through the master codebook. So most country projects maintain a separate coding system that meets the needs of the particular country, but also code their policy observations into the master system.

A second requirement necessary to maintain comparability is that if new topics are subtopics are added, all older topics relevant to the new topic must be examined throughout the full series of observations and re-coded into the new system if necessary. This requirement is termed "backward comparability", because it insures that as the time series of policy activity moves forward, the topics remain comparable (Jones, 2016). 
The American Political Science Association's Comparative Politics Section noted in its citation awarding the CAP system its 2019 Lijphart / Przeworski / Verba Dataset Award that the system "represents a global collaboration that rests on a common, harmonized codebook and approach by which team members use various inputs to code policy priorities, discussion, efforts, and outcomes". The citation goes on to note "The committee was impressed by the project's open and inclusive spirit, the latter evidenced by the project's extensive network of collaborators and various activities that bring together a diverse set of researchers using the CAP data... Owing to their Herculean efforts, their due diligence, and their commitment to data access and transparency, the project has left an indelible mark on the field of comparative politics".

\section{WITH EACH EXPANSION OF THE CAP COME NEW OPPORTUNITIES AND INSIGHTS}

Expansion of the CAP into a number of Latin American countries provides a number of opportunities. Beyond the obvious fact of allowing more direct comparisons of political processes from countries already included in the CAP to a new set of countries not previously included, the specific context of Latin American politics also provides some novel theoretical approaches. Here we can assess the future by looking at the past. The history of previous expansions of the CAP provides some insights.

A major insight that developed from the CAP experience came at its first expansion from the US to other systems: Governments have more similarities than differences. When Agendas and Instability in American Politics was first published (Baumgartner \& Jones, 1993), its language of "multiple venues" and complications of federalism may have struck some comparative scholars as peculiarly American, with little possible applicability in political systems that do not feature separation of powers, weak political parties, or strong local or subnational governments. But the book has been widely used because its focus on policy dynamics and long-term frame shifts has proved more widely applicable than might have seemed likely at first.

The geographic center of gravity of the CAP as of today is undoubtedly within the European Union, not in the US or North America. Moving to Europe brought a number of opportunities and theoretically interesting questions. Probably foremost among those was attention to the degree that actions from the EU in Brussels were affecting national policymaking in the member states. Implementation of EU Directives typically implies national level legislation, but these legislative acts are more or less mandatory. Such a process has led to less parliamentary involvement in important policy negotiations. Executives are involved in the EU-level negotiations before a Directive emerges from Brussels. But once it does, there is little a legislative party, whether in opposition or a member of the majority coalition, can do other than pass the required implementing legislation without amendment. Studying the impact of EU regulations has been an important part of the CAP community throughout the EU member states, and even in the Swiss case, since while not a member of the EU, the Swiss government still must maintain compliance with various EU regulations in order to promote the single market. These were far from the theoretical concerns that started the CAP, and they are mostly irrelevant for the US project. The generic and broadly applicable nature of the CAP databases allow the easy and systematic study of these issues even 
though they were not envisioned when the CAP began. Having a bigger telescope allows one to see things even if the telescope was not initially designed to look for them.

Of course, the comprehensive nature of the CAP databases allows for questions that were not part of the previous literature because previous empirical approaches did not allow for them. Jones and Baumgartner (2005) addressed such issues as agenda-scarcity, stochastic budget modeling, and the concept of the "threshold of attention" (being affected not only by the severity of an underlying problem, but also by the cumulative severity of the other problems simultaneously of concern to the government). Their analysis, among the first to be conducted based on comprehensive databases of the CAP, pushed the literature into areas that were literally not previously addressed.

More recently, Bryan Jones, Sean Theriault, and Michelle Whyman (2019) have pushed further, exploring the causes and consequences of the "Great Broadening" in the scope of US politics in the post-war period. They argue that the very nature of the US government and political system was dramatically, radically, and permanently altered in a burst of activities into uncharted policy domains in the growth of activities associated with the Great Society and subsequent programs such as expansion of environmental regulations and civil rights concerns in the 1960s. These expansions altered power relations and expanded the scope of government to such an extent that there was no going back. Most importantly, assessing these shifts in government would not have been possible with a single focus on such indicators as the relative tax burden or the size of the federal budget as a share of GDP. Rather, the databases of the CAP allowed a documentation of something that could not otherwise have been seen: The emergence of government, its spread, into areas where it had not previously been an important actor. Once the government spread, it did not recede, and the political debate went on to something different: How to manage the administrative state.

\section{LATIN AMERICAN CAP PROJECTS}

At present, six different country teams - Argentina, Brazil, Chile, Colombia and Ecuador and México - have developed comprehensive datasets for analyzing agenda dynamics in a comparative perspective (see Box 1). These datasets provide a unique instrument for the analysis of the policy agenda in three policy venues - Parliament, the Government and the Media - across time and countries. These datasets cover a period of one or two decades, with some exceptions, like the case of speeches of the President in Mexico, which covers a period of 50 years, from the 1960s to present. 
RAP | Agenda dynamics in Latin America: theoretical and empirical opportunities

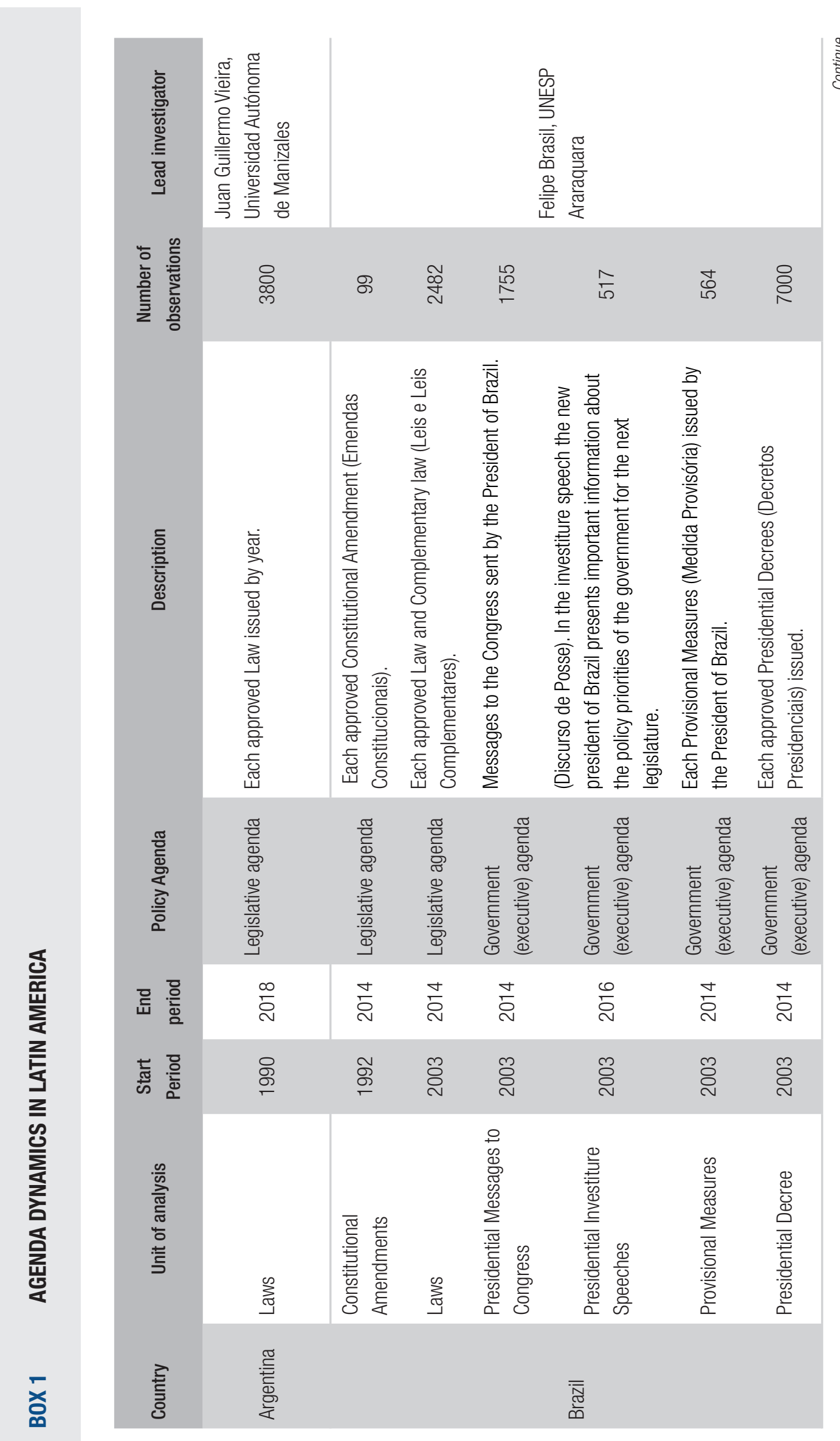

Brazilian JOURnal of PUblic administration ｜ Rio de Janeiro 54(6):1513-1525, Nov. - Dec. 2020 
RAP | Agenda dynamics in Latin America: theoretical and empirical opportunities

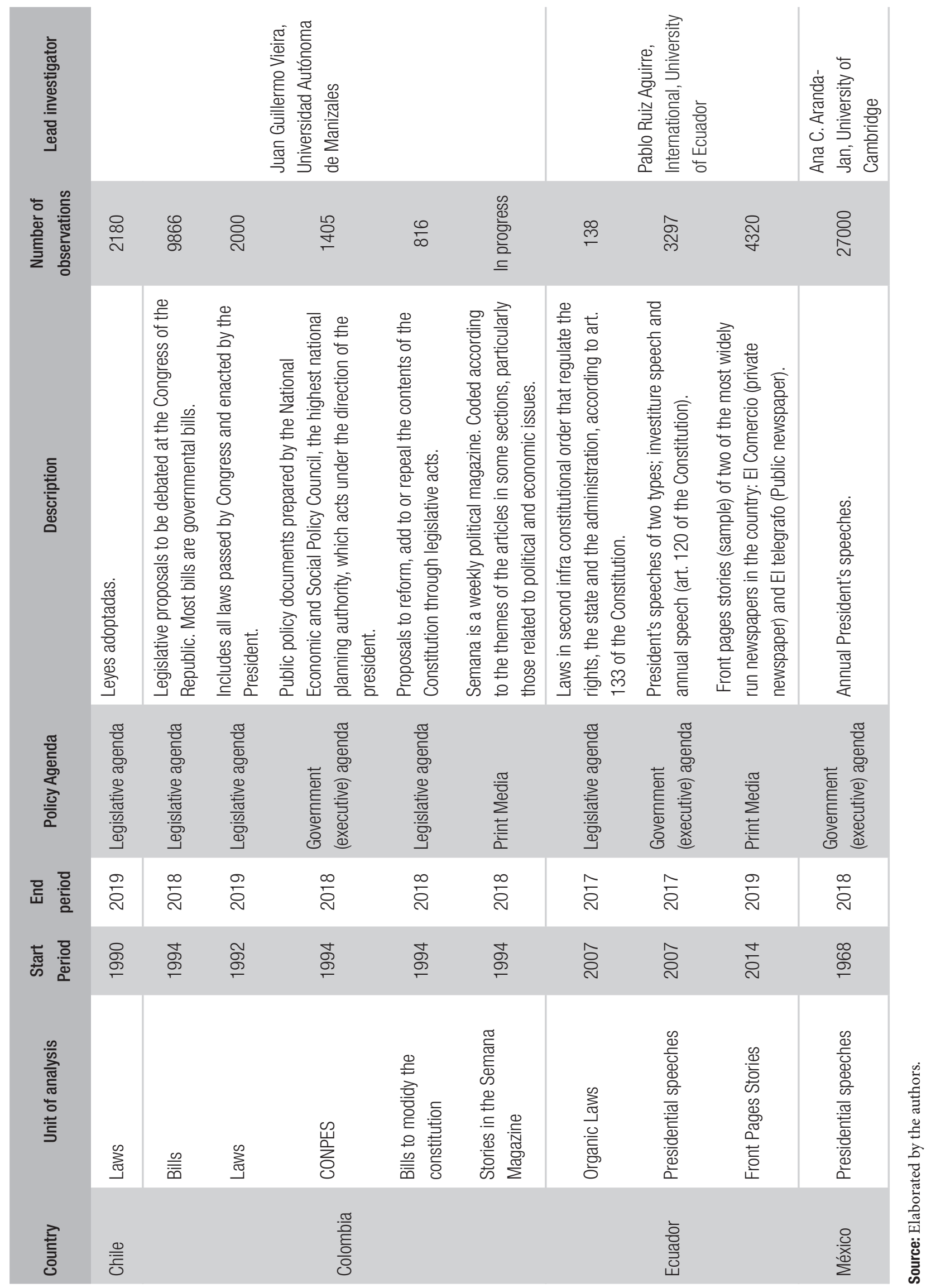

Brazilian JOURnal of Public administration ｜ Rio de Janeiro 54(6):1513-1525, Nov. - Dec. 2020 
To study the agendas of the executive, three country teams - Brazil, Ecuador, and México - developed datasets about the policy content of presidential speeches. Generally, all executive speeches include policy proposals rather than announcements of policy actions. In the case of Brazil, this includes investiture speeches, as the president of Brazil makes no other type of annual speech. In contrast, in Ecuador and México, the datasets about the agenda of the executive include the annual speeches of the President, which follows quite similar characteristics of the annual speeches in other countries (see Baumgartner et al., 2019a). As in many other democratic countries, in the investiture speech the head of the executive presents the executive's program of government, providing important information about the policy priorities of the executive for the next legislature. In contrast, all other annual speeches follow a similar pattern as the state of the nation speech that takes place annually. In this case, the President informs the nation about the policy priorities for the rest of the legislature, as well as about the evolution and implementation of the electoral program, informing about variations in the content of the governmental agenda since the beginning of the term.

For the analysis of the substantive agenda of the executive, in which executives announce actual policy actions rather than proposed actions, two countries, Brazil and Colombia, developed different datasets. The Brazil team developed a dataset that contains information about presidential decrees. These are regulatory acts taken by the executive. In formal terms, these are decisions the executive takes in cases of extraordinary and urgent need, when exceptional circumstances make it impossible to follow ordinary legislative procedure. The question is whether, as in many other countries, the president is increasingly using this legislative instrument to take decisions about issues that have nothing to do with urgent necessities. In the case of Colombia, the CAP team developed a dataset about bills, which contains all information about the legislative proposals issued by the government and also parliamentary groups. As in many other countries, the supremacy of the executive in the political system is illustrated by the high percentage of bills initiated by the government that are finally passed into laws, compared to bills initiated by parliament. Hence, these dataset provides a relevant instrument to study the asymmetric relationship between the government and the parliament that characterizes most advanced democracies.

For the analysis of parliamentary agendas, country teams have created different datasets including the bills introduced by parliamentary groups. Some countries, like Colombia, have also created a dataset about parliamentary bills. As in other democracies, these are more attention-seeking devices than acts designed to generate legislation. Moreover, different CAP teams have developed datasets about organic and/or ordinary laws in Argentina, Brazil, Chile, Colombia and Ecuador. Finally, the country team of Ecuador has developed a dataset centering on the media agenda, which covers a sample of stories in the front pages of two of the most widely run newspapers in the country, El Comercio, which is a private newspaper, and El Telegrafo, which is a public newspaper. As in other cases (see Walgrave et al., 2019), the analysis is mainly about front-page stories because they are important indicators of the prioritization of issues by media outlets, a quantifiable indicator of the relevance and newsworthiness of issues according to editors and journalists. 
All the databases have been coded twice by human coders, following the CAP codebook. The first task these country teams undertook, before starting the coding procedure, was to adapt the codebook to the peculiarities of their countries. In most cases, this meant to adapt existing descriptions that better inform about the peculiarities of each country. In other countries, this included the creation of new categories aimed to capture aspects that have no equivalent in other countries. Colombia is the only case that undertook these changes. In particular, Colombia created a new code (50) to account for Domestic Conflict and Peace Processes, which is a crucial problem in Colombian politics for the last decades.

There have been challenges in adopting the Comparative Policy Agendas framework into the Latin American context, but none of these challenges differ in kind from the experiences of European research teams. Language, expansion to a new set of countries, economic context, international actors, are similar to the challenges research teams had in moving into European countries from the U.S. system. Are there codes or policy domains that will need to be added, or any that will not be used? Can the country-specific coding system be integrated reasonably easily into the CAP master codebook? Do we need to think of databases or indicators that are not used in the EU or US context, such as debt, international aid, or trade indicators? Must we incorporate the priorities and activity levels of such actors as the international lending community? Note that these are not theoretical problems, simply contextual covariates that may be of interest to collect. Such an approach would be similar (at least methodologically) to incorporating EU Directives into the analysis of the dynamics of member state government agendas.

It is important to remember that CAP is a measurement system. It captures variation in policy agendas and policy actions across political systems in a systematic manner such that these variations can be quantitatively analyzed. The system can be used from the perspective of various theoretical perspectives. And qualitative work is essential to complement CAP-based quantitative policy process studies. CAP researchers have shown that governments tend to pursue similar policies, but at different times and intensities.

These variations do not explain themselves; there will always be roles for qualitative analyses and area studies. The integration of the strong intellectual tradition in qualitative Latin American Studies with the quantitative work emerging from the CAP research teams in Latin America has powerful scholarly and practical potential.

\section{CONCLUSIONS}

Expansion of the CAP to the Latin American context presents numerous theoretical and practical opportunities. Theoretically, it expands to a new context the range of empirical observations, inevitably allowing better tests of existing theories as well as tests of new ones. If the past is any predictor of the future, more new questions will be addressed than we can currently envision. One obvious area of investigation may be the impact of neo-liberal policy reforms initiated or encouraged by certain international lending agencies on the domestic agendas and activities of Latin American countries. Similar to assessing the impact of EU Directives within the EU-CAP countries, these outside actors may have had a substantial impact on the domestic agenda, and on the distribution of power between executives and legislatures. However, different Latin American leaders have adopted the policies of 
RAP | Agenda dynamics in Latin America: theoretical and empirical opportunities

international lending agencies with more or less enthusiasm (or sometimes, refused them outright). Thus, the range of response may well be greater within the countries of the LA-CAP than we have previously seen in the EU.

Building a bigger telescope invites new discovery. As the CAP expands into this new territory, we can expect many benefits. 


\section{REFERENCES}

Baumgartner, F. R., Breunig, C., \& Grossman, E. (2019a). The Comparative Agendas Project: Intellectual Roots and Current Developments. In F. R. Baumgartner, C. Breunig, \& E. Grossman. (Eds.), Comparative Policy Agendas: Theory, Tools, Data. (pp. 3-16). New York, NY: Oxford University Press.

Baumgartner, F. R., Breunig, C., \& Grossman, E. (Eds.). (2019b). Comparative Policy Agendas: Theory, Tools, Data. New York, NY: Oxford University Press.

Baumgartner, F. R., \& Jones, B. D. (1993). Agendas and Instability in American Politics. Chicago, IL: University of Chicago Press.

Baumgartner, F. R., \& Jones, B. D. (2015). The Politics of Information. Chicago, IL: University of Chicago Press.

Chaqués Bonafont, L., Roqué, A. M. P., \& Baumgartner, F. R. (2015). Agenda Dynamics in Spain. London, UK: Palgrave Macmillan.

Engeli, I., Green-Pedersen, C., \& Larsen, L. T. (Eds.). (2012). Morality Politics in Western Europe: Parties, Agendas and Policy Choices. London, UK: Palgrave Macmillan.

Erikson, R. S., Stimson, J. A., \& MacKuen, M. (2002). The Macro Polity. New York, NY: Cambridge University Press.

Green-Pedersen, C., \& Mortensen, P. B. (2010). Who Sets the Agenda and Who Responds to it in the Danish Parliament? A New Model of Issue Competition and Agenda-Setting. European Journal of Political Research, 49(2), 257-281.
Jones, B. D. (2016). The Comparative Policy Agendas Projects as Measurement Systems. Journal of Public Policy, 36, 31-46.

Jones, B. D., \& Baumgartner, F. R. (2005). The Politics of Attention: How Government Prioritizes Problems. Chicago, IL: University of Chicago Press.

Jones, B. D., Baumgartner, F. R., Breunig, C., Wlezien, C., Soroka, S. N., Foucault, M. ... Walgrave, S. (2009). A General Empirical Law for Public Budgets: A Comparative Analysis. American Journal of Political Science, 53(4), 855-873.

Jones, B. D., Baumgartner, F. R., \& True, J. L. (1998). Policy Punctuations: US Budget Authority, 1947-95. Journal of Politics, 60(1), 1-33.

Jones, B. D., Theriault, S. M., \& Whyman, M. (2019). The Great Broadening: How the Vast Expansion of the Policymaking Agenda Transformed American Politics. Chicago, IL: University of Chicago Press.

Seeberg, H. B. (2013). The Opposition's Policy Influence through Issue Politicization. Journal of Public Policy, 33(1), 89-107.

Soroka, S. N., \& Wlezien, C. (2010). Degrees of Democracy: Politics, Public Opinion, and Policy. New York, NY: Cambridge University Press.

Stimson, J. A. (1999). Public Opinion in America: Moods, Cycles, and Swings (2nd ed.). Boulder, CO: Westview.

Wlezien, C. (1995). The Public as Thermostat: Dynamics of Preferences for Spending. American Journal of Political Science, 39(4), 981-1000.

Wlezien, C., \& Soroka, S. N. (2012). Political Institutions and the Opinion-Policy Link. West European Politics, 35, 1407-1432. 


\section{Frank R. Baumgartner}

https://orcid.org/0000-0003-4193-4152

Is the Richard J. Richardson Distinguished Professor of Political Science at the University of North Carolina at Chapel Hill. E-mail: fbaum@email.unc.edu

\section{Bryan D. Jones}

Is the J. J. "Jake" Pickle Regent's Chair in Congressional Studies in the Department of Government at the University of Texas at Austin. E-mail: bdjones@austin.utexas.edu

\section{Laura Chaqués Bonafont}

https://orcid.org/0000-0002-0724-4871

Professor of Political Science at the University of Barcelona, and research fellow at the Institut Barcelona d'Estudis Internacionals (IBEI). E-mail: lchaquesbonafont@gmail.com 